\title{
PELATIHAN PENULISAN RESENSI KARYA SASTRA DI SMK GIRI TARUNA 2 BOGOR
}

Dwi Septiani ${ }^{1}$, Siti Maemunah ${ }^{2}$, Awla A.I. ${ }^{3}$, Varatisha A.A. ${ }^{4}$ 1,2,3,4, Fakultas Sastra, Universitas Pamulang, Banten

E-mail :dosen01401@unpam.ac.id ${ }^{1}$,dosen02349@unpam.ac.id², dosen01664@unpam.ac.id ${ }^{3}$ ,dosen01471@unpam.ac.id ${ }^{4}$

Submitted : 26 Februari 2021 Accepted: 22 Agustus 2021 Published: 31 Agustus 2021

\begin{abstract}
Abstrak : Dalam pembelajaran di tingkat SMA/SMK, khususnya di kelas XI SMK, para siswa diharapkan dapat mengembangkan kemampuan menulis. Salah satu materi pembelajaran yang berhubungan dengan keterampilan menulis resensi karya sastra. Salah satu permasalahan yang ditemukan dalam pembelajaran Bahasa Indonesia terkait keterampilan menulis, khususnya penulisan resensi karya sastra. Menulis resensi karya sastra merupakan salah satu keterampilan yang menuntut keterampilan membaca kritis serta perbendaharaan kata yang luas sehingga dapat menarik pembaca dengan kata-kata yang bervariasi. Oleh karena itu, metode yang digunakan dalam pengabdian ini adalah berupa pelatihan menulis resensi karya sastra yang baik dan benar. Hasil kegiatan penelitian ini adalah melalui pelatihan menulis resensi karya sastra, siswa kelas XI di SMK Giri Taruna 2 Bogor termotivasi untuk membaca kritis karya sastra serta membuat karya tulis berupa resensi karya sastra. Pelatihan secara daring ini diikuti oleh 32 siswa dan 2 guru pendamping. Hasil kuesioner terkait evaluasi kualitas pelatihan penulisan resensi dari peserta pelatihan (siswa), yakni siswa mendapatkan dampak positif dalam pembelajaran bahasa Indonesia $(4,88)$; siswa mampu menulis resensi karya sastra setelah mengikuti program pelatihan $(4,81)$; dan gaya instruktur pelatihan penulisan resensi karya sastra dalam penyampaian materi dan Suasana selama pelatihan berlangsung serius dan menyenangkan $(4,75)$. Oleh karena itu, dapat disimpulkan bahwa pelatihan penulisan resensi karya sastra di SMK Giri Taruna 2 Bogor dinyatakan bermanfaat bagi para peserta (siswa kelas XI SMK).
\end{abstract}

Kata kunci: pelatihan, menulis, resensi, SMK Giri Taruna 2 Bogor 


\section{PENDAHULUAN}

Ada beberapa keterampilan penting yang harus dipelajari siswa saat mereka berpindah dari satu tahap ke tahap lainnya di bidang akademik nantinya. Keterampilan ini diajarkan di sekolah untuk memaparkan kepada siswa tentang berbagai cara yang dapat dilakukan untuk memecahkan masalah kehidupan nyata kapan pun mereka dihadapkan pada masalah tersebut. Di antara semua ini adalah menulis, yang tidak dapat disangkal, salah satu keterampilan terpenting yang harus disempurnakan setiap siswa.

Menulis, sebagai keterampilan itu sendiri, menawarkan siswa kesempatan untuk secara bersamaan menangkap banyak fasilitas penting lainnya yang dapat membantu mereka berhasil dalam akademis, karier, dan juga dalam aspek lain yang relevan dalam kehidupan mereka. Salah satu penelitian yang berkaitan dengan penulisan resensi adalah karya Agustin (2017) berjudul "Peningkatan Kemampuan Menulis Resensi Novel Menggunakan Strategi Pemodelan". Terdapat penjelasan bahwa keterampilan menulis teks resensi pada novel rendah akibat kurangnya antusias peserta didik dalam membaca dan strategi pembelajaran yang digunakan kurang efektif. Dengan demikian, seolah wajar, banyak siswa yang tampaknya tidak memahami pentingnya menulis dalam kehidupan mereka. Itulah sebabnya, dalam artikel ini, akan dipaparkan beberapa pentingnya menulis dan mengapa itu sangat penting bagi siswa. Cahyaningrum, dkk. (2018) menjelaskan bahwa kompetensi menulis sangat penting untuk diajarkan pada berbagai jenjang pendidikan. Dalam dunia pendidikan, kemampuan menulis merupakan salah satu keterampilan yang diutamakan dalam perkembangan dan perkembangannya, selain membaca dan berhitung. Dengan salah satu materi pembelajaran resensi, peserta didik dapat melatih keberanian dalam menulis untuk menyampaikan informasi kepada pembaca, untuk itu diperlukan adanya keterampilan yang baik untuk menulis sehingga apa yang ingin disampaikan sesuai dengan apa yang diharapkan (Murahmanita, et al, 2021).

Endah, dkk (2012) berpendapat bahwa kemampuan menulis dapat dikembangkan melalui tahapan yang mudah yaitu dari mengamati, bertanya, menalar, dan mencoba. Demikian pula, Kusmana (2014: 15) juga menyatakan bahwa derajat ini juga berlaku saat menulis review. Melalui tahap menulis penilaian, setiap individu juga berlatih untuk meningkatkan keterampilan menulisnya. Seperti yang dijelaskan oleh Nugraha, dkk. (2018), kegiatan menulis merupakan kegiatan yang perlu dipraktekkan secara terus menerus. Kemampuan menulis ini juga akan meningkat jika didukung oleh sarana kegiatan belajar dan kekayaan kosa katanya.

Salah satu keterampilan menulis yang diajarkan di SMK kelas XI adalah menulis resensi. Materi menulis resensi adalah salah satu materi kelas XI SMK yang ada di dalam Kurikulum 2013 Revisi 2017 semester genap, tepatnya pada empat Kompetensi Dasar (KD): KD 3.16 Membandingkan isi berbagai resensi untuk menemukan sistematika sebuah resensi; KD 4.16 Menyusun sebuah resensi dengan memerhatikan hasil perbandingan beberapa teks resensi; 3.17 Menganalisis kebahasaan resensi setidaknya dua karya yang berbeda; 4.17 Mengkonstruksi sebuah resensi dari buku kumpulan cerita pendek atau novel yang sudah dibaca.

Sebelum melakukan penulisan resensi halhal yang harus dilakukan untuk meningkatkan kemampuan menulis melalui kegiatan evaluasi buku, faktor pertama yang harus dilakukan adalah mengetahui dasar-dasar keterampilan menulis resensi. Reviewer sering diistilahkan dengan pengulas sebuah karya sehingga menciptakan sebuah resensi buku, resensi buku, dan sebagainya (Dalman, 2016: 125). Seperti yang dirujuk oleh Montazeran (2012), resensi buku adalah suatu jenis penilaian dari 
suatu faktor sudut pandang yang diperlukan di mana reviewer memikirkan secara mendalam dan kritis unsur tentang bagianbagian dari buku yang diulas sehingga dapat menilai kualitas dari suatu buku.Resensi sastra biasanya dimuat di koran atau majalah (Kusmarwanti \& Nurhadi, 2020).

Senada dengan pendapat di atas, Fardengki et al. (2012) mengatakan bahwa review merupakan hasil evaluasi atau penimbangan kekuatan dan kelemahan sebuah buku. Dengan demikian, dapat diartikan bahwa resensi adalah tulisan yang membahas dan menilai suatu karya tulis tentang kualitas karya tulis yang tepat dan buruk. Teks resensi memiliki tingkat perhatian yang tinggi karena teks resensi faktanya merupakan konten tekstual yang dihasilkan dari analisis mendalam terhadap suatu isu dengan melibatkan beberapa hal sebagai pertimbangan sehingga dapat menyajikan evaluasi yang adil, objektif, dan rasional terhadap suatu isu dan konten tekstual sedang ditinjau. Kastiyawan, dkk (2007) juga menyebutkan bahwa teks resensi adalah teks yang memuat kritik, evaluasi, atau evaluasi atas karya hak cipta intelektual. Teks resensi menuntut objektivitas dalam menilai karya sastra agar tidak subjektif, misalnya karena suka atau tidak suka pada pribadi pengarangnya (Pohan, 2014).

Salah satu tujuan utama dalam mempelajari cara menulis resensi adalah untuk memahami bagaimana cara atau sistematika dalam memberikan penilaian terhadap karya sastra seseorang dengan sebaik-baiknya (Khasanah, 2021). Di sisi lain, menurut Mohammad, et al (2021), tujuan resensi dalam proses pembelajaran, yaitu memberikan informasi atau pemahaman yang komprehensif tentang apa yang tampak dan terungkap dalam sebuah buku, mengajak pembaca untuk memikirkan, merenungkan, dan mendiskusikan lebih jauh fenomena atau problematik yang muncul dalam sebuah karya yang diresensi, dan memberikan pertimbangan kepada pembaca apakah karya tersebut pantas mendapat sambutan dari masyarakat atau tidak.

Dalam membahaca dan mengkaji suatu karya tulis, penulis resensi akan mengungkapkan aspek-aspek keunggulan dan kelemahan dari karya tulis tersebut secara keseluruhan dan objektif yang diperoleh dari buku yang diresensi dan disampaikan kepada masyarakat. Menilai sebuah buku atau karya sastra berarti memberi saran kepada para pembaca secra keseluruhan untuk menolak atau menerima kehadiran buku tersebut. Seorang penulis resensi harus tetap berusaha untuk menimbulkan dan memberi kesan kepada pembaca bahwa penilaiannya telah diberikan secara tepat dan dilakukan secara objektif. Dalam mengembangkan sebuah karya resensi, seorang pencipta harus mempelajari dan mengetahui langkah-langkah penilaian yang tepat untuk mendapatkan hasil akhir review yang objektif dan pembaca bisa mendapatkan poin-poin yang tepat tentang kekuatan dan kelemahan dari karya tersebut.

Resensi atau evaluasi karya sastra dapat digunakan sebagai sarana untuk mengungkapkan pikiran dan gagasan dari siswa tentang kualitas dari karya tersebut. Namun, kurangnya pembinaan dan persiapan dari guru membuat banyak siswa terbebani saat melakukan review. Potensi menulis resensi buku dapat memberikan gambaran yang jelas tentang suatu buku atau karya sastra yang diulas bagi pembaca dan dapat memotivasi pembaca resensi untuk ikut membaca buku atau karya sastra itu.

Berdasarkan wawancara dengan salah satu guru SMK, diketahui bahwa mayoritas siswa kelas XI SMK masih kurang memahami bagaimana menulis resensi dengan baik. Melihat fakta tersebut, kami dari Program Studi Sastra Indonesia bersama dengan Lembaga Penelitian dan Pengabdian Kepada Masyarakat (LPPM) Unpam untuk melakukan kegiatan Pengabdian Kepada Masyarakat (PKM) secara daring dengan tema "Pelatihan 
Penulisan Resensi Karya Sastra di SMK Giri Taruna 2 Bogor" sebagai wujud nyata pengabdian dosen kepada masyarakat untuk mengabdikan Tri Darma Perguruan Tinggi. Kegiatan ini lebih mengutamakan kepada aktivitas nyata kepada siswa SMK yang dapat memberikan manfaat sebagai pengetahuan tentang penulisan resensi karya sastra yang baik dan benar. Hal ini berdasarkan pada Pasal 20 UU No. 20 Tahun 2003 tentang Sistem Pendidikan Nasional (UU DIKNAS) dan berdasarkan pasal 24 UU Diknas yang menyatakan bahwa adanya otonomi oleh Perguruan Tinggi untuk mengelola sendiri lembaganya sebagai pusat penyelenggaraan pendidikan tinggi, penelitian ilmiah, dan pengabdian kepada masyarakat.

Dengan adanya kegiatan yang dilakukan oleh civitas akademika Universitas Pamulang khususnya Prodi Sastra Indonesia yang melakukan kegiatan pengabdian kepada masyarakat diharapkan dapat menjadi modal sebagai peran nyata pengamalan ilmu yang dimiliki guna memenuhi kebutuhan hidup masyarakat, khususnya para siswa SMK Giri Taruna 2 Bogor.

\section{TINJAUAN PUSTAKA}

Dalam proses pelatihan keterampilan menulis resensi, ada banyak yang disampaikan oleh pamateri utama, yakni Dr. (Cand) Awla Akbar Ilma, calon Doktor S-3 Ilmu-Ilmu Humaniora (Sastra) Universitas Gajah Mada, terkait dengan materi penulisan resensi karya sastra. Secara umum, ada tiga poin utama dari pelatihan ini, yakni proses pertama adalah penyampaian materi pengajaran dan pembelajaran tentang keterampilan menulis resensi; paparan selanjutnya adalah tentang nilai, strategi, dan langkah-langkah dalam praktik penulisan resensi; paparan tentang prinsip-prinsip dasar resensi, dan langkahlangkah praktik menulis resensi.
Sebelum menulis sebuah resensi, penulis resensi harus memahami terlebih dahulu prinsip-prinsip dasar menulis resensi. Potter J.W. (1998) menyatakan prinsip dasar resensi adalah membaca buku dan mencoba masuk ke dalam ide, gagasan atau tujuan penulis untuk memahami apa yang dia coba capai, dengan akurat dalam ulasan yang akan ditulis. Senada dengan Dalman (2016: 120-125) yang berpendapat bahwa peresensi (orang yang melakukan kegiatan resensi) harus menyadari sepenuhnya tujuan meresensi, serta harus memahami latar belakang pembacanya. Sebuah karya tulis resensi tidak bisa ditulis secara sembarangan saja, melainkan harus menggunakan prinsip penulisan resensi yang telah ada. Dengan berdasar atau mengacu pada prinsip-prinsip dasar resensi seorang peresensi dapat menghasilkan sebuah resensi yang nilainya dapat dipertanggungjawaabkan.

Sebagaimana yang dikatakan oleh Budi (2013: 50-51) penulis resensi wajib secara teliti dan cermat mengetahui berabagi prinsip dari penulisan resensi dan juga ciri khas dari tiap media massa cetak atau non-cetak sehingga karya resensi bisa diterbitkan secara tepat dan seminim mungkin adanya perbaikan atau suntingan. Dalam menulis resensi prinsipprinsip dasar ini dapat mempermudah para penulis resesi. Dengan prinsip dasar resensi, penulis resensi akan menyadari sepenuhnya tujuan menulis resensi tersebut, hal tersebut sangat menentukan corak resensi. Dalam prinsip dasar resensi juga mengharuskan penulis resensi memahami betul latar belakang pembaca yang menjadi sasarannya.

Penulis resensi juga harus mengetahui kebijakan dan resensi macam apa yang disukai oleh redaksi agar resensi yang dibuat dapat dimuat di surat kabar atau majalah. Dari pendapat tersebut, dapat disimpulkan bahwa seorang penulis resensi harus menyadari sepenuhnya tujuan meresensi, harus memahami latar belakang pembacanya, serta mengetahui latar belakang pembaca atau 
mengetahui siapa sasaran pembaca yang akan dituju dianggap penting sebab selain bisa membantu penulis resensi mampu merancang poin-poin yang mau dipaparkan ke dalam karya tulisnya.

Selain mengetahui prinsip-prinsip dasar menulis resensi, peresensi juga perlu memahami terlebih dahulu langkah-langkah yang harus ditempuh untuk menyusun teks resensi. Berkenaan dengan itu (Daniel dalam Dalman, 2016) memberikan lima langkah-langkah membuat resensi, yaitu: (1) penjajakan atau pengenalan terhadap buku mulai dari tema buku, identitas penerbit, dan siapa pengarangnya; (2) membaca buku secara komprehensif, cermat dan teliti, (3) menandai bagian-bagian buku yang dianggap khusus atau penting; (4) membuat sinopsis atau intisari buku; (5) menentukan sikap dan menilai organisasi penulisan isi, bahasa, dan aspek teknis sebagai faktor yang perlu diperhatikan bahwa resensi buku harus bermanfaat bagi pembaca.

Wee dan Banister (2016) menjelaskan bahwa sebuah resensi dapat menguraikan keuntungan dan kerugian dari metode yang digunakan dan implikasi temuan yang dibahas. Selain itu, Kuncoro (2009: 12-15) juga menyampaikan ada lima langkah menulis resensi. Pertama, memahami dan menangkap tujuan pengarang. Kedua, memiliki tujuan dalam membuat resensi. Ketiga, harus mengetahui selera pembaca. Keempat, mempunyai pengetahuan berbagai disisplin ilmu pengetahuan sebagai tolak ukur. Kelima, menjadi pengamat buku sekaligus kolektor buku. Pada tahap terakhir penulis resensi juga harus mengoreksi dan mengevaluasi hasil tulisannya. Tulisan resensi yang kurang tepat atau bahkan membingungkan para pembaca dapat segera diketahui dan diperbaiki. Hal tersebut penting dilakukan karena resensi sangat mempengaruhi pembaca dalam menentukan pilihannya.

\section{METODE PENELITIAN}

Kegiatan pelatihan ini dilaksanakan pada Senin, 8 Maret 2021, pukul 09.00-15.00 WIB. Adapun narasumber atau pemateri utama diisi oleh dosen ahli di bidang sastra, yakni Dr.(Cand) Awla Akbar Ilma, 1 orang Moderator, dan 2 orang Pendukung Teknis serta jumlah peserta 32 siswa kelas XI SMK Giri Taruna 2 Bogor yang mengisi kehadiran di WAG yang sudah dibuat khusus untuk peserta pelatihan ini. Adapun informasi yang harus disertakan adalah Nama Lengkap Peserta, Kelas, dan Jurusan. Hal ini diperlukan untuk penerbitan sertifikat peserta pelatihan.

Metode yang digunakan adalah sejenis pelatihan dengan terlebih dahulu memaparkan teori terkait resensi, resensi karya sastra, penulisan resensi karya sastra, sampai sesi diskusi atau sesi tanya jawab. Proses pembinaan dan pelatihan ini lebih banyak menggunakan teknik motivasi (motivation), inkuiri (pencarian), dan teknik ceramah dengan pemanfaatan media dalam jaringan (daring), yakni Zoom Meeting. Teknik motivasi dan inkuiri digunakan dengan tujuan agar meningkatkan minat dalam keterampilan menulis resensi. Untuk metode ceramah, dimaksudkan untuk memperdalam materi dan memperkaya khasanah pengetahuan tentang menulis resensi yang tepat. Sesuai dengan kerangka pemecahan masalah di atas, kegiatan ini menyajikan materi, yaitu: (1) pelatihan materi teoritik (pengajaran dan pembelajaran pelatihan keterampilan menulis resensi pada siswa kelas XI SMK Giri Taruna 2 Bogor; minat atau motivasi diri dalam keterampilan menulis; nilai, strategi, dan langkah-langkah menulis resensi) dan (2) pengetahuan praktis (materi menulis resensi yang tepat; keterampilan menulis resensi yang tepat, mulai dari penggalian ide, proses penulisan, proses penyuntingan, dan pengembangan menulis resensi). 
Selain itu, tahap penting lainnya adalah tahap evaluasi. Evaluasi kualitas pengabdian ini diukur dengan cara pengisian kuesioner oleh peserta pelatihan sebagai umpan balik terhadap pengabdian kepada masyarakat dengan menggunakan lima penilaian kualitas pelatihan penulisan resensi karya sastra dengan, yakni (1) Sangat Tidak Setuju, (2) Kurang Setuju, (3) Cukup, (4) Setuju, dan (5) Sangat Setuju. Kuesioner evaluasi tersebut berisi 15 pernyataan dan diisi oleh 32 siswa (100\%) yang telah mengikuti serangkaian pelatihan. Berikut ini hasil evaluasi yang diisi oleh 32 peserta pelatihan.

\section{HASIL DAN PEMBAHASAN}

Dalam menulis review, sudah sepatutnya mengevaluasi sebuah karya atau buku baru. Pendapat lain diungkapkan Putra (2008: 78) yang menyatakan bahwa ada tahapan penulisan resensi dari sebuah buku. Tahapan tersebut adalah (1) membaca buku secara lengkap untuk mendapatkan foto buku yang lengkap, (2) menganalisis pendahuluan dan pendahuluan untuk mendapatkan gambaran menyeluruh tentang buku tersebut, (3) mencatat kelebihan dan kekurangan buku tersebut, (4) memeriksa fakta yang ada di dalam buku (5) meneliti hal-hal detail di buku. Dari pendapat tersebut, dapat disimpulkan bahwa komponen yang paling diperlukan dalam menulis resensi sebuah karya sastra atau review karya sastra adalah penulis resensi harus memiliki keakuratan, ketelitian, dan manfaat resensi tersebut agar menguntungkan bagi pembacanya. Selain itu, penulis resensi juga wajib memiliki pemahaman dan wawasan yang luas serta mengetahui bagaimana etika dan gagasan dalam menulis resensi buku.

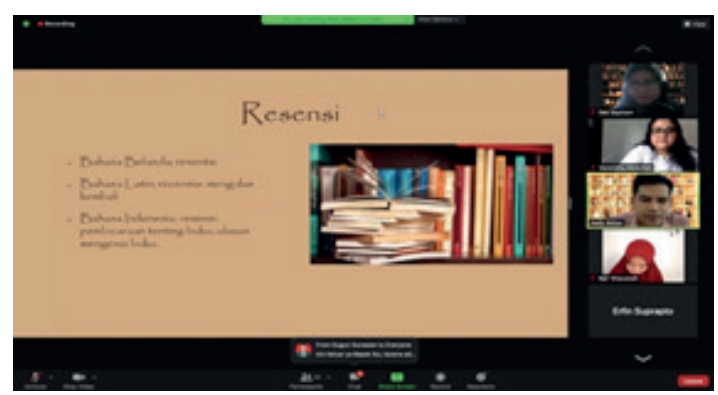

Gambar 1: Pemaparan Penulisan Resensi Karya Sastra oleh Dr.(Cand) Awla Akbar Ilma

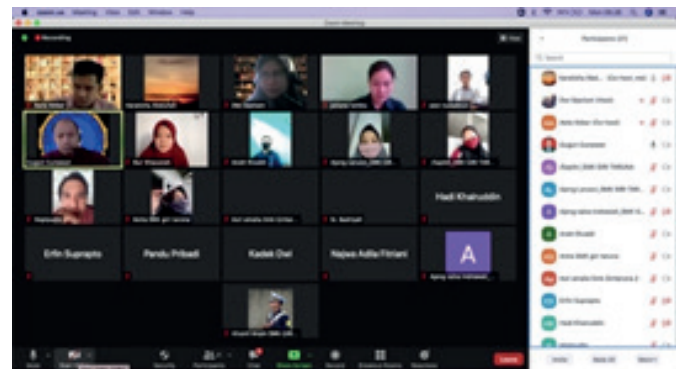

Gambar 2: Tim PKM dan Para Peserta Berfoto Setelah Pelatihan Selesai

Hasil dari kegiatan pelatihan keterampilan menulis resensi siswa ini adalah peserta siswa mampu menulis resensi dengan baik dan tepat. Selain itu, ada tahap yang sangat penting dalam pelatihan ini, yaitu evaluasi yang diberikan oleh para peserta pelatihan, yakni 32 siswa. Pada tahap ini, tim dosen melakukan tahap evaluasi yang akan dilakukan pada saat kegiatan pelatihan selesai. Tahap evaluasi ini berisikan evauasi dari peserta terkait kualitas dari pelatihan penulisan resensi karya sastra yang telah diikutinya. Di sisi lain, ada pula tahap pelaporan kegiatan PKM ini akan dibuat sebagai bahan evaluasi yang akurat agar pada kegiatan pengabdian kepada masyarakat selanjutnya sebagai salah satu realisasi Tri Dharma Perguruan Tinggi menjadi lebih baik lagi. Berikut ini adalah tabel terkait evaluasi yang diisi oleh 32 peserta setelah mengikuti pelatihan penulisan karya sastra melalui media Zoom Meeting. 
Tabel 1 Evaluasi Pelatihan Penulisan Resensi di SMK Giri Taruna 2 Bogor

\begin{tabular}{|c|l|c|}
\hline No. & \multicolumn{1}{|c|}{ Indikator Evaluasi Pelatihan Penulisan Resensi } & $\begin{array}{c}\text { Nilai } \\
\text { Rata- } \\
\text { Rata }\end{array}$ \\
\hline & \multicolumn{1}{|c|}{ A. Reaksi } & 4,75 \\
\hline 1 & Gaya instruktur pelatihan penulisan resensi karya sastra dalam penyampaian materi & 4,75 \\
\hline 2 & Suasana selama pelatihan berlangsung serius dan menyenangkan & 4,25 \\
\hline 3 & Ketepatan dan kesesuaian waktu & 4,66 \\
\hline 4 & Materi pelatihan yang menarik & 4,65 \\
\hline 5 & Waktu pelatihan tepat waktu & 4,12 \\
\hline & B. Pembelajaran Selama Pelatihan & 4,16 \\
\hline 6 & Dapat menerima materi resensi yang diberikan oleh pelatih & 4,75 \\
\hline 7 & Bertambahnya pengetahuan tentang apresiasikarya sastra setelah mengikuti pelatihan & 4,81 \\
\hline 8 & Mampu menerapkan ilmu yang didapat selama pelatihan & \\
\hline 9 & Mampu menulis resensi karya sastra setelah mengikuti program pelatihan & 4,19 \\
\hline 10 & \begin{tabular}{l} 
Ada peningkatan pengetahuan khusus tentang keterampilan menulis resensi karya \\
\hline \\
\hline
\end{tabular} Castra setelah mengikuti program pelatihan & 4,88 \\
\hline 11 & Mendapatkan dampak positif dalam pembelajaran bahasa Indonesia & 4,19 \\
\hline 12 & Meningkatkan minat baca karya sastra & 4,22 \\
\hline 13 & Lebih produktif dalam menulis, khususnya resensikarya sastra & 4,19 \\
\hline 14 & Meningkatkan semangat atau minat belajar bahasa Indonesia & 4,09 \\
\hline 15 & Meningkatkan prestasibelajar bahasa Indonesia & \multicolumn{1}{|c|}{} \\
\hline
\end{tabular}

Dari tabel di atas, diketahui bahwa ratarata penilaian tertinggi yang diberikan oleh peserta adalah peserta dominan setuju mendapatkan dampak positif dalam pembelajaran bahasa Indonesia (4,88). Posisi kedua terkait evaluasi kualitas pelatihan penulisan resensi karya sastra yang diisi oleh dominan para peserta adalah mampu menulis resensi karya sastra setelah mengikuti program pelatihan. Terakhir, evaluasi pelatihan yang disampaikan oleh mayoritas peserta adalah "gaya instruktur pelatihan penulisan resensi karya sastra dalam penyampaian materi dan suasana selama pelatihan berlangsung serius dan menyenangkan $(4,75)$. Berdasarkan hasil evaluasi kualitas pelatihan penulisan resensi karya sastra di SMK Giri Taruna 2 Bogor, dapat disimpulkan bahwa pelatihan penulisan resensi karya sastra yang diselenggarakan oleh tim PKM Programx Studi Sastra Indonesia, Universitas Pamulang, yang terdiri dari Dwi Septiani, Siti Maemunah, Awla A.I., dan Varatisha A.A. bisa dikatakan sangat bermanfaat bagi para peserta, tepatnya para siswa kelas XI SMK Giri Taruna 2 Bogor.

\section{KESIMPULAN}

Berdasarkan paparan pada bagian di atas, simpulan dari pelatihan penulisan resensi karya sastra ini adalah para siswa kelas XI SMK mendapat banyak ilmu dan pengetahuan terkait resensi karya sastra. Hal ini sejalan dengan pendapat Septiai, et al (2020) bahwa dengan menulis, seseorang tidak hanya menggambarkan satu ide, tetapi juga dapat memberikan dan memanfaatkan pemikiran dan struktur bahasa dalam dalam ragam tulis sehingga mudah dimengerti maksudnya oleh siapa saja. Para siswa (peserta) merasa pelatihan menulis resensi ini sangat bermanfaat sehingga mereka merasa mampu untuk menulis resensi karya sastra sesuai arahan dari pemateri. Hal tersebut dibuktikan dari hasil sangat positif tentang kuesioner evaluasi terkait penilaian peserta pelatihan (siswa) mendapatkan dampak positif dalam pembelajaran bahasa Indonesia $(4,88)$. Posisi kedua terkait evaluasi kualitas pelatihan penulisan resensi karya sastra yang diisi oleh dominan para 
peserta adalah Mampu menulis resensi karya sastra setelah mengikuti program pelatihan $(4,81)$. Posisi ketiga evaluasi pelatihan yang disampaikan oleh mayoritas peserta adalah "Gaya instruktur pelatihan penulisan resensi karya sastra dalam penyampaian materi dan Suasana selama pelatihan berlangsung serius dan menyenangkan $(4,75)$.

Adapun saran untuk kegiatan pengabdian kepada masyarakat atau pelatihan selanjutnya adalah mengusung pelatihan lain yang terkait dengan keterampilan berbahasa lainnya, seperti keterampilan berbicara (retorika) dan keterampilan menulis karya ilmiah atau populer untuk para guru dan juga para siswa. Dengan demikian, melalui beragam pelatihan keterampilan kebahasaan tersebut akan bermanfaat untuk guru dan juga para siswa SMK Giri Taruna 2 Bogor dalam proses pembelajaran bahasa Indonesia.

\section{UCAPAN TERIMAKASIH}

Tim Pengabdian Kepada Masyarakat (PKM) Program Studi Sastra Indonesia, Universitas Pamulang mengucapkan terima kasih kepada kepada LPM Unimed atas terbitnya jurnal PKM ini. Selain itu, tak lupa juga kami menyampaikan terima kasih kepada Universitas Pamulang, LPPM Universitas Pamulang, para dosen dan mahasiswa Prodi Sastra Indonesia Unpam, dan segenap civitas akademika SMK Giri Taruna 2 Bogor yang sangat proaktif dalam menyukseskan kegiatan pelatihan penulisan resensi karya sastra ini.

\section{DAFTAR PUSTAKA}

Agustin, M. (2017). "Peningkatan Kemampuan Menulis Resensi Novel Menggunakan Stategi Pemodelan”. Jurnal Diksatrasia, 1(2).

Budi, T. (2013). Jurnal Pendidikan. Jakarta: Badan Pendidikan Kristen Penabur (BPK Penabur).

Cahyaningrum, F., Andayani, K.S. (2018).
Peningkatan Keterampilan Menulis Argumentasi Melalui Model Think Pair Share dan Media Audiovisual Pada Siswa Kelas X-10 SMA Negeri Kebakkramat. Jurnal Pendidikan dan Kebudayaan, 3 (1). 45. doi: http://dx.doi.org/ 10.24832/jpnk.v3i1.605.

Dalman. (2016). Keterampilan Menulis. Jakarta: PT. Raja Grafindo Persada.

Endah, N., Sumarwati, Kundharu S. (2012). Analisis Kesalahan Berbahasa Indonesia Siswa Sekolah Menengah Atas. Penelitian Bahasa, Sastra Indonesia dan Pengajarannya, 1 (1), 40-53.

Fardengki, E., Ena N. (2012). Korelasi Kemampuan Membaca Pemahaman dan Kemampuan Menulis Resensi Siswa Kelas IX SMP Negeri 3 Linggo Sari Bagati, Jurnal Pendidikan Bahasa dan Sastra Indonesia, 1 (1), 639-645. doi: https://doi.org/10.24036/1378-019883.

Kastiyawan, M. Agus, H., Ahmad, A. (2017). Pengembangan Media Levidio Storyboard Dalam Pembelajaran Menulis Teks Ulasan Film/Drama Pada Siswa Kelas XI SMK. Journals of Culture, Arts, Literature, and Linguistics. 3 (1). 21-22. doi: http://dx.doi.org/10.30872/ calls.v3i1.774.

Khasanah, Z. (2021). Pengaruh Penggunaan Model Pembelajaran Role Playing dalam Meningkatkan Kemampuan Menulis Resensi Siswa Kelas XI MAN 2 Palembang (Doctoral dissertation, 021008 Universitas Tridinanti Palembang).

Kuncoro, M. (2009). Mahir Menulis. Jakarta: PT Gelora Aksara Pratama.

Kusmarwanti, K., \& Nurhadi, N. (2020). Kopi dalam Sejumlah Resensi Sastra di Koran Nasional Indonesia. Diksi, 28(2), 145-154.

Mohammad, R. R. H., Maknun, T., \& Lewa, I. (2021). Peningkatan Kemampuan Siswa Sma Negeri 4 Kota Palu Dalam Menu- 
lis Resensi Film Laskar Pelangi Melalui Model Discovery Learning. Jurnal Al Qiyam, 2(1), 26-36.

Murahmanita, M., Nasrah, S., \& Trisfayani, T. (2021). Pengaruh Penggunaan Media Audio Visual Terhadap Keterampilan Menulis Teks Resensi Siswa Kelas XI SMKS Ulumuddin Lhokseumawe. KANDE (Jurnal Pendidikan Bahasa Indonesia), 1(1), 109-117.

Nugraha,V., Indra P., Aditya P. (2018). Pembelajaran Menulis Resensi Novel Pertemuan Dua Hati Dan Laskar Pelangi Menggunakan Tekni. Jurnal Ilmiah UPT P2M STKIP Siliwangi, 5 (2). 55. doi: https://doi.org/10.22460/p2m. v5i2p55-61.966.

Potter, W. James. (1998). Media Literacy. California: Sage Publications.

Putra. (2008). Langkah-Langkah Meresensi Buku. Jakarta: Depdiknas.

Septiani, D., Saragih, D. K., \& Maulinda, R. (2020). Pengaruh Minat Belajar dan Kesantunan Berbahasa terhadap Prestasi Penulisan Teks Diskusi Siswa Kelas VIII SMPN 21 Tangerang Selatan. GERAM, 8(1), 48-59.

Tim Penyusun. (2003). Undang-Undang No. 20 tahun 2003 Tentang Sistem Pendidikan Nasional. Jakarta.

Wee, B. Van, \& Banister, D. (2016). How to Write a Literature Review Paper ? Transport Reviews, 0(0), 1-11. https://doi.org/ 10.1080/01441647.2015.1065456

Yulidar br. Pohan, E. (2014). Pengaruh Model Pembelajaran Collaborative Learning Terhadap Kemampuan Menulis Resensi Cerpen oleh Siswa Kelas XI SMA Persiapan Stabat Tahun Pembelajaran 2013/2014. Jurnal Basastra, 3 (4), 6-7. doi: https://doi.org/10.24114/bss. v3i4.1459. 